\title{
The influence of water management and environmental con- ditions on the chemical composition and beverage quality of coffee beans
}

\author{
Emerson A. da Silva ${ }^{1,2, *}$, Paulo Mazzafera ${ }^{2}$, Orivaldo Brunini ${ }^{1}$, Emílio Sakai ${ }^{1}$, Flávio B. Arruda ${ }^{1}$, Luiz Hen- \\ rique C. Mattoso ${ }^{3}$, Cássia R. L. Carvalho ${ }^{4}$ and Regina Célia M. Pires ${ }^{1}$
}

${ }^{1}$ Centro de Pesquisa e Desenvolvimento de Ecofisiologia e Biofísica, Instituto Agronômico de Campinas, CP 23, CEP 13020-902, Campinas, SP, Brasil; ' $D$ Departamento de Fisiologia Vegetal, Instituto de Biologia, Universidade Estadual de Campinas, CEP 13083-971, Campinas, SP, Brasil; ${ }^{3}$ Centro Nacional de Pesquisa e Desenvolvimento de Instrumentação Agropecuária - EMBRAPA, CEP 13560-970, São Carlos, SP, Brazil; ${ }^{4}$ Centro de Pesquisa e Desenvolvimento de Recursos Genéticos Vegetais, Instituto Agronômico de Campinas, CEP 13020-902, Campinas, SP, Brasil. *Corresponding author: easilva@ibot.sp.gov.br

Received: 10/04/2005, Accepted: 17/06/2005

The influence of environmental conditions and irrigation on the chemical composition of green coffee beans and the relationship of these parameters to the quality of the beverage were investigated in coffee plantations in the regions of Adamantina, Mococa and Campinas, in the state of São Paulo, Brazil. The chemical composition and physical aspects of green coffee beans produced in the three regions were related through Principal Component Analyses (PCA) to the quality of beverage, as determined by sensorial and electronic analyses. The chemical composition was affected by the environmental conditions. Some differences in cup quality were detected by the electronic method but not by cup tasting. Irrigation was not a major factor affecting chemical composition, since there were few differences in relation to non-irrigated coffee plants. The production site appeared to be the main influencing factor on biochemical composition. A pronounced difference was observed in Adamantina, where annual average air temperature was $1.6-2.4^{\circ} \mathrm{C}$ warmer than in the other two areas and about $3.5^{\circ} \mathrm{C}$ above to the optimal limit for coffee cultivation.

Key words: air temperature, beverage, coffee quality, nitrogen compounds.

Influência de condições ambientais e da irrigação na composição química e na qualidade de bebida do café: A influência das condições ambientais e do manejo da irrigação na composição química do grão de café verde e sua relação com a qualidade de bebida foram investigadas em cafeeiros cultivados nas regiões paulistas de Adamantina, Mococa e Campinas. A composição química e alguns aspectos físicos dos grãos de café verde produzidos nos diferentes tratamentos e locais de cultivo foram relacionados à qualidade de bebida determinada por análises sensoriais e eletrônicas. Os dados tratados por análises de componentes principais demonstraram que a composição química dos grãos permitiu a diferenciação do café produzido em diferentes regiões, sendo as variações na composição das sementes perceptíveis na análise da bebida pelo método eletrônico, mas não pelas análises sensoriais. A irrigação não foi fator condicionante na composição química dos cafés, com pouca ou nenhuma diferença significativa em relação a cafeeiros não irrigados, sendo tais diferenças condicionadas pelo local de cultivo, as quais, acredita-se, seriam influenciadas pela temperatura do ar, que foi, em média, 1,6 a 2,4 $4^{\circ} \mathrm{C}$ mais alta em Adamantina em relação, respectivamente, a Mococa e Campinas, e cerca de $3,5^{\circ} \mathrm{C}$ acima do limite de temperatura considerado ótimo para o cultivo do cafeeiro.

Palavras-chave: café, compostos nitrogenados, qualidade da bebida, temperatura do ar. 


\section{INTRODUCTION}

Several studies have attempted to establish a relationship between the chemical composition of green coffee beans with beverage quality, seeking substances or precursors which may underlie the acceptance or rejection of the beverage (Clifford, 1985). Although a difficult task, proteins, amino acids, carbohydrates and phenolic compounds have been indicated as important compounds for the development of a good coffee beverage (Clifford, 1985; 1997; Rogers et al., 1999a, b; Shimizu and Mazzafera, 2000; Selmar et al. 2001; Montavon et al., 2003a,b). The action of polyphenoloxidase (Amorim and Amorim, 1977) and proteases (Ludwig et al., 2000) upon some of these constituents has also been suggested to play a role in determining the quality of coffee although the importance of polyphenoloxidase in this respect has been questioned (Mazzafera et al., 2002).

The concentrations and the mechanisms of action for the compounds mentioned above and how they affect the beverage quality remain unknown (Montavon et al., 2003a). However, in addition to the genetic background (Carvalho, 1988; Scholz et al., 2001) and the harvesting and postharvesting procedures (Clarke, 1985; Vincent, 1985) the production of good quality coffee beans in specific areas, characterized by their climatic conditions clearly shows that the climate is an important factor in determining the quality of the coffee beverage. Despite their evident agronomic importance, the influence of environmental factors such as climate, soil, cultivation practices and irrigation has not been extensively investigated (Njoroge, 1998). In Brazil, it is well established that coffee beans from certain regions such as Minas Gerais State, give better cup quality. It is believed that the lower mean temperature of certain localities in this state plays an important role in the development of attributes conferring good quality. Although lacking scientific support, it is commonly considered by farmers that at lower temperature coffee fruits undergo a slower maturation process compared with coffee fruits from warmer regions, allowing the full manifestation of all biochemical steps necessary for the development of beverage quality. Two reports have shown that this phenomenon may indeed occurs in Arabica coffees (Guyot et al., 1996; Decazy et al., 2003) but unfortunately in both studies actual temperatures were not recorded.

Decazzy et al. (2003) evaluated the quality of the Honduran coffees studying 52 plots of Arabica coffee spread throughout six producing regions. Principal components analysis based on the chemical composition (lipids, caffeine, trigonelline and chlorogenic acid contents), agronomical characteristics (shade, vigor, yield), environmental factors (rainfall, altitude, latitude and longitude), and degree of roasting, allied to sensorial classification of the beverage indicated that the best coffees were obtained at altitudes above $1,000 \mathrm{~m}$, where the annual rainfall remained below $1500 \mathrm{~mm}$. In addition, the more acidic coffees had a higher content of lipids, sucrose and chlorogenic acid. An inverse relationship was observed between the lipid content and rainfall. To our knowledge, this is the only study that has attempted to establish a relationship between environmental factors, chemical composition and coffee quality.

In Brazil, coffee is cultivated under a large range of edapho-climatic conditions, and cultivation has spread to new areas previously classified as inappropriate because of the low rainfall or poor rainfall distribution throughout the year. According to Camargo et al. (1992), large variations in rainfall and temperature are responsible for the range of coffee types (from Rio type to gourmet) found in Brazil. However, no study has specifically assessed the influence of different cultivation practices, including irrigation, on coffee quality. Most investigations so far have focused mainly on the effects of irrigation on coffee productivity and on the synchronization of flowering (Carr, 2001).

Another aspect that has hindered the establishment of a relationship between chemical composition of coffee and the quality is the subjective nature of beverage classification. Statistical studies suggested that the sensorial classification done by trained tasters is susceptible to errors (Carvalho et al., 1994). For this reason, the use of an artificial sensor known as the "electronic tongue" (Ferreira et al., 2003; Riul Jr. et al., 2003), capable of distinguishing different solutions and concentrations in parts per billion (ppb) has proved to be a more reliable approach in differentiating coffee quality.

In this study we have evaluated the influence of three distinct edapho-climatic conditions and the use of irrigation on the chemical composition of green coffee bean and attempted to establish a relationship with cup quality.

\section{MATERIAL AND METHODS}

Plant material, edapho-climatic conditions, harvesting and sample preparation: Coffee seeds were harvested from Arabica coffee trees (Coffea arabica L. cv. Obatã IAC 166920) approximately 3.5 years old. The trees were cultivated as a hedgerow $2.5 \times 1.0 \mathrm{~m}$ spaced, unshaded, in three municipalities in the state of São Paulo, Brazil, from July 2001 to May 2002: Adamantina (AD) $\left(21^{\circ} 41^{\prime} \mathrm{S}, 51^{\circ} 05^{\prime} \mathrm{W}\right.$, altitude $443 \mathrm{~m})$, Mococa (MC) $\left(21^{\circ} 28^{\prime} \mathrm{S}, 47^{\circ} 01 \mathrm{~W}\right.$, altitude 
$663 \mathrm{~m})$ and Campinas (CP) $\left(22^{\circ} 54^{\prime} \mathrm{S}, 47^{\circ} 05^{\prime} \mathrm{W}\right.$, altitude 669 $\mathrm{m}$ ). The soils of the three localities were classified (Soil Survey Staff, 1996) as Rhodic eutrustox (Adamantina), Typic hapludult (Mococa) and Rhodic eutrudox (Campinas) (Prado, 2003). The normal annual mean air temperature and total rainfall for Adamantina, Mococa and Campinas were $23.1,21.8$ and $20.7^{\circ} \mathrm{C}$, and 1165,1442 and $1382 \mathrm{~mm}$, respectively (data from the Centro Integrado de Informações Agrometeorológicas - Instituto Agronômico de Campinas - http://www.iac.sp.gov.br/ciiagro/), which classifies these localities as macroclimate Cwa as defined in the Köppen International Classification (Russo Jr., 1984). During the experimental period the mean air temperature (Ta) and the total rainfall were obtained at fortnightly intervals from automated weather stations located approximately $500 \mathrm{~m}$ from the test areas.

At all three localities the plants were distributed using a random experimental design and the irrigation treatments applied were: non-irrigated (NI), continuous irrigation (CI) and irrigation suspended for 30 days in July (I30) and 60 days in July and August (I60). Each treatment involved ten plants. A surface dripping irrigation system was used to provide $4 \mathrm{~mm}$ of water per day in the treatments receiving irrigation. This value was determined based on the mean daily evapotranspiration at Adamantina (3.8 mm), Mococa (3.2 $\mathrm{mm})$ and Campinas $(3.4 \mathrm{~mm})$.

Fruits were harvested by stripping the branches over a sieve and the fruit weight for each plant was recorded. Since Silva (2004) observed that continuous irrigation retards coffee ripening and knowing that immature coffees affect coffee quality (Mazzafera, 1999), only fully ripe fruits were selected (cherries) and dried on sieves maintained in full sunlight. The dried fruits were stored in paper bags at $10 \%$ humidity and used for chemical and sensorial evaluations. For each plant, the dried fruits were dehusked and the fresh weight of 100 grains was obtained as well as the mean grain size (MSS), calculated by the mean sieve method (Krug, 1940). Soil analyses were carried out for the three experimental plots and during the experiment the coffee plants were fertilized as recommended (Fazuoli et al., 1998).

Chemical analysis: Although coffee production was determined using ten plants, the chemical analyses were carried out with five compost replicates prepared from ten plants. Total soluble sugars, reducing sugars, sucrose, total soluble phenolic compounds, chlorogenic acid (5-caffeoylquinic acid/ 5CQA), caffeine, soluble protein and soluble amino acids, were determined in the same ethanolic extract. The seeds were freeze-dried and finely ground in a ball mill. Extraction $(50 \mathrm{mg}$ in $5 \mathrm{~mL}$ ethanol/water $80 \%$ ) was carried out in screw capped tubes at $60^{\circ} \mathrm{C}$ for $2 \mathrm{~h}$, with occasional agitation. The samples were then centrifuged in a bench top centrifuge $(12,000 \mathrm{rpm})$ for $10 \mathrm{~min}$, and the supernatants were stored at $-20^{\circ} \mathrm{C}$ until analysis. The pellets from the centrifugation were extracted with $2 \mathrm{ml}$ of $90 \%$ dimethylsulfoxide (DMSO) for $16 \mathrm{~h}$ at room temperature, with constant agitation. After this period, the samples were centrifuged $(3,000 \mathrm{rpm})$ and the DMSO fraction used for the determination of starch, using glucose as standard (McReady, 1959).

The concentrations of soluble sugars (McReady, 1959), reducing sugars (Nelson, 1944); sucrose (van Handel, 1968), phenolics (Swain and Hillis, 1959) and amino acids (Cocking and Yemm, 1954) were determined by colorimetry. Caffeine and 5CQA were determined by reversed-phase high performance liquid chromatography (RP-HPLC) (Mazzafera, 1997). Sucrose was used as a standard for the sucrose and soluble sugar determinations, glucose for reducing sugars, phenol for phenolic compounds and leucine for amino acids. Pure caffeine and 5CQA were used as standards in the HPLC determinations.

Lipid, total protein and total nitrogen contents were also measured in the samples. Lipids were extracted from $500 \mathrm{mg}$ of seed meal in $5 \mathrm{~mL}$ of hexane in a screw-capped tube and kept in a water-bath at $60^{\circ} \mathrm{C}$ for three days. Hexane was recovered by centrifugation and the lipid concentration obtained by colorimetry (Chabrol and Charonnat, 1937). Proteins were extracted from $100 \mathrm{mg}$ of seed meal in $5 \mathrm{ml}$ of $0.1 \mathrm{~N} \mathrm{NaOH}$ for $12 \mathrm{~h}$, and the concentration was determined according to Bradford (1976). The standards for the lipid and protein determinations were, respectively, linoleic acid and bovine serum albumin. Total nitrogen was determined on 100 mg samples by the Kjeldahl method (Pearson, 1976).

The polyphenoloxidase (PPO) activity was determined by measuring oxygen consumption with 5CQA as substrate (Mazzafera and Robinson, 2000; Mazzafera et al., 2002). Protease activity was assayed with azocasein as substrate (Oliveira et al., 2002) using the same extract as for PPO.

Sensorial evaluation: Three professional tasters carried out sensorial assessment of the coffee samples. An overall criterion, named global quality, was used to classify the quality of each beverage. This criterion includes the aroma, body, acidity and bitterness and is based on a hedonic scale from 0 (absence of the criterion) to 5 (presence). 
Sensorial evaluation was also done using an "electronic tongue". This method is based on the conductivity of six electrodes made of polymers and lipid-like materials that are capable of promptly detecting very low concentrations ( $\mathrm{ppb}$ ) of saline, sweet, bitter and acidic solutions (Riul Jr. et al., 2003). This electronic tongue has been used to characterize coffee beverages by comparisons with the classifications provided by coffee tasters (Ferreira et al., 2003). For this analysis, $200 \mathrm{~g}$ of each dry-processed coffee was roasted $\left(180-200^{\circ} \mathrm{C}\right.$ for $8 \mathrm{~min}$ in a sample roaster TC-0 - Pinhalense) and ground in a knife mill (model TMC-10, Pinhalense, Espírito Santo do Pinhal, SP, Brazil) to a granulometry of 50-40 mesh. The beverage was prepared by brewing $10 \mathrm{~g}$ of the ground coffee in $100 \mathrm{~mL}$ of boiling deionized water.

Statistical Analysis: The data from the chemical analyses were subjected to ANOVA and, when test $F$ was significant, the means were compared using Duncan's test at $5 \%$ probability. The differences among the three localities were evaluated by principal components analysis (PCA), using the Pirouette 2.2 Computer Program (Pirouette, 1997). PCA is a mathematical manipulation of the data matrix designed to reduce the original dimension of the data matrix and is based on the correlation among the variables, with those that are highly correlated being grouped into a new variable called the principal component. This new set of axes and coordinates, in which the data are projected, is more informative and smaller in number than the original variables (Morgano et al., 1999). From a mathematical point of view, the matrix of data is decomposed into two matrices, one consisting of scores and the other of loadings. In our analysis, data on the chemical composition, weight of 100 seeds, mean seed size and global quality of the beverage were previously self-scaled because of differences in magnitude of each of these parameters. The self-scaling corresponded to a pre-processing of the original data and consisted of centering the data on the average and dividing them by the respective standard deviation.

\section{RESULTS AND DISCUSSION}

Seasonal variation of mean air temperature and rainfall: Figure 1 shows the variations in mean air temperature (Ta) and rainfall over the period from June 2001 to May 2002, in Adamantina, Mococa and Campinas. During this period, the respective Ta's at these localities were $24.7,22.9$ and $22.3^{\circ} \mathrm{C}$ (figure 1A). It is noteworthy that the Ta of Adamantina was on average 1.6 and $2.4^{\circ} \mathrm{C}$ higher than Ta's of Mococa and Campinas, respectively. In contrast, the rainfall was lower at Adamantina (1128 mm) compared to Mococa (1602 mm) and Campinas (1273 mm) (figure 1B).

According to the climatic phenological model proposed by Camargo and Camargo (2001) for C. arabica in Brazil, the fruit setting period, when the seeds develop inside the fruit, occurs from January to March and a drought during this period can result in fruit drop. As shown in figure 1B, from January to March the rainfall at Adamantina was lower than at the other localities, being more discrepant when compared with Mococa. For the three localities, March was an atypical month since in the first 15 days of the month the rainfall was significantly lower than in the other periods. The rainfall data should be considered together with the Ta data. Therefore, it is evident that during fruit set not only was the water availability lower in Adamantina but the Ta was higher than Mococa and Campinas. Several reports have suggested that coffee growth is affected by temperatures higher than $30^{\circ} \mathrm{C}$ (Cannell, 1985) Based on the data available for coffee quality and Brazilian climatic conditions, Camargo et al. (1992) suggested that regions with a relatively high temperature tend to produce low quality coffee.

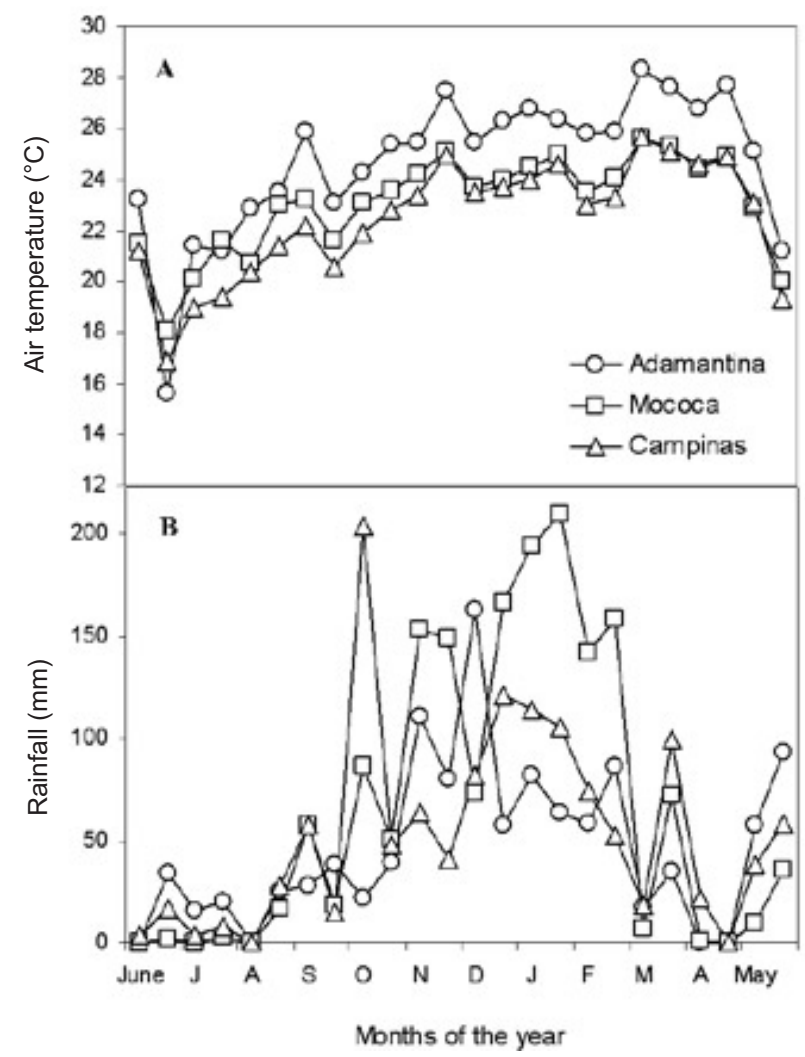

Figure 1. Variations in the air temperature (A) and rainfall (B) over the period from June 2001 to May 2002, in Adamantina, Mococa and Campinas 
Chemical composition and beverage quality: Irrigation had no effect on the chemical composition of coffee beans from Adamantina, Mococa and Campinas (table 1). With the exception of protease activity, for which the non-irrigated (NI) controls had lower values, none of the other analyses showed a similar tendency with respect to irrigation.

In agreement with previous analyses (Clifford, 1985; Mazzafera, 1999; Rogers et al., 1999b), sucrose represented on average $80 \%$ of the total soluble sugars. Except for Campinas $(r=0.278)$ there was an inverse relationship between the sucrose concentration and that of reducing sugars in Adamantina $(r=-0632)$ and Mococa $(r=-0.762)$ such that lower concentrations of sucrose were associated with higher concentrations of reducing sugars. This finding is consistent with the increase in sucrose and decrease in reducing sugars during the final stages of seed growth in coffee fruits (Rogers et al., 1999b).

Phenolic compounds accounted for 12 to $16 \%$ of the seed composition. 5CQA, the main chlorogenic acid isomer found in coffee seeds, did not vary significantly among the treatments. Chlorogenic acid may contribute to the final acidity of the beverage, with some effect on flavor and aroma (Trugo et al., 1984; Clifford, 1985; Moreira et al. 2001).

Caffeine concentrations ranged from $7.7 \mathrm{mg} \cdot \mathrm{g}^{-1}$ and 11.3 $\mathrm{mg} / \mathrm{g}$ and there were few differences among treatments or localities, although coffee seeds from Campinas tended to have more caffeine. Similarly, the lipid content did not vary significantly among treatments or localities, although coffee from Mococa tended to have higher values. Although most of the lipids are lost during grinding, these are important components for the beverage and aroma (Folstar, 1985). During roasting, lipids expelled by beans can form a layer on the bean surface that may trap volatile aromas, thereby impairing the immediate loss of these compounds (Clifford, 1985). Recently, Decazzy et al. (2003) reported that coffee trees grown at high altitudes $(>1,000 \mathrm{~m})$ produce beans with a higher concentration of lipids and yielded better cup quality. However, according to these authors, the role of the lipids in the sensory quality of coffees remains to be elucidated.

Although the pattern of irrigation had no effect on the chemical composition of coffees from the same locality, marked differences were observed among the three localities, suggesting an effect of the area in which the plants were grown. These differences were most evident for nitrogenous compounds. PCA showed that coffee from Adamantina differed significantly from that produced in Mococa and Campinas (figures 2A and 2B).

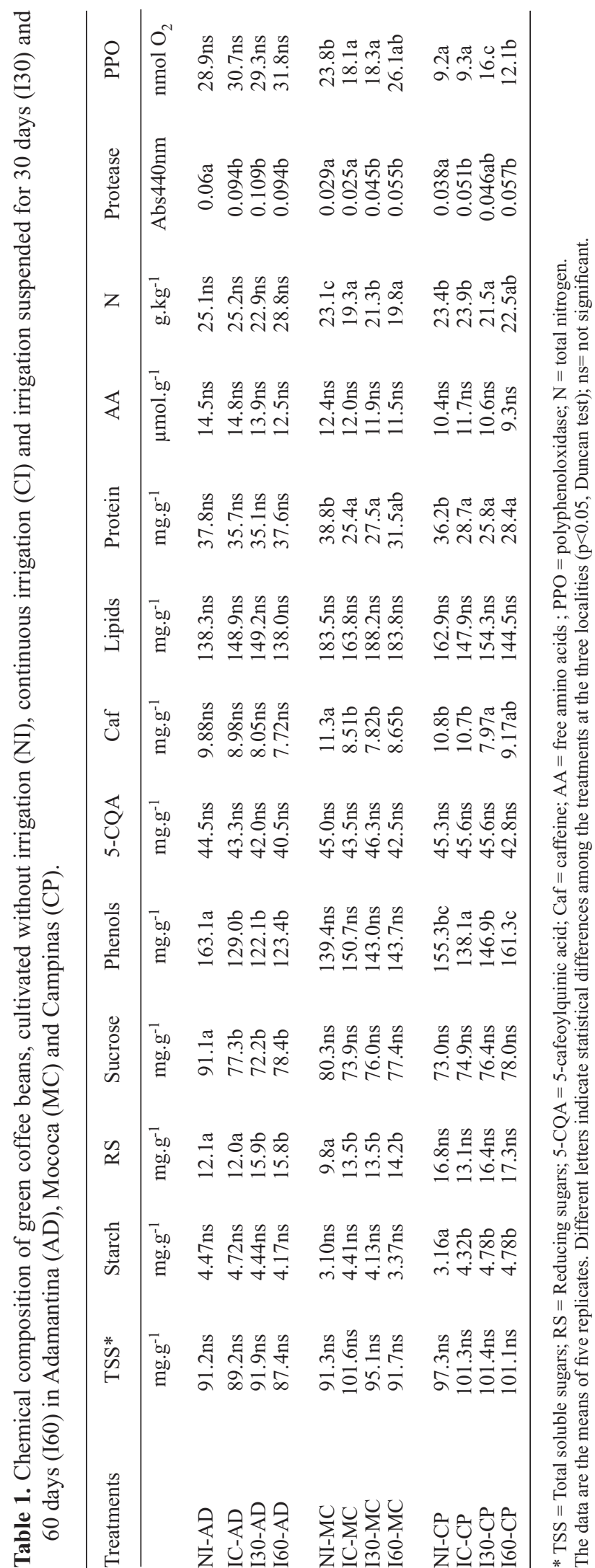

Braz. J. Plant Physiol., 17(2):229-238, 2005 
The loading diagrams provided by PCA (figures $2 \mathrm{C}$ and 2D) showed that proteins, amino acids, total nitrogen and protease and PPO activities differed for localities and were always higher in Adamantina, were they accounted for 30.5\% of the variation. Amino acids and peptides are important components of coffee aroma, mainly because of the Maillard reaction that occurs between amino acids and carbohydrates, particularly sucrose. However, the mechanisms that define the proportion of free amino acids and peptides remain unknown (Montavon et al., 2003a).

Proteolytic activity was detected in coffee beans, as previously reported by Ludwig et al. (2000), with greater activity in beans from Adamantina. Plant proteases are classified as endopeptidases, aminopeptidases and carboxypeptidases (Barret, 1986), all of which degrade proteins into smaller peptides and release amino acids. Since the concentrations of total soluble sugars, amino acids and proteases were greater in Adamantina, differences were expected in the quality of the beverage among coffees from the three localities.

Another enzyme that has been related to the quality of coffee is PPO. A high content of this enzyme has been associated with good quality coffee (Amorim and Amorim, 1977; Amorim and Melo, 1989). PPO was highest in coffee from Adamantina, although the activities for the three localities were lower than values reported in the literature for coffee using $\mathrm{O}_{2}$ consumption as the activity parameter (Mazzafera, 1999; Mazzafera and Robinson, 2000). However, these authors analyzed coffee beans during the development of the fruit and not after processing and storage.

The correlation coefficient for the relationship between phenol content and PPO activity was negative for coffee from Adamantina $(r=-0,602)$ and Mococa $(r=-0.556)$, but not from Campinas $(r=0.068)$. When calculated for 5CQA the coefficients were $-0.720,-0.516$ and 0.040 for Adamantina, Mococa and Campinas, respectively. According to Amorim and Amorim (1977) the low PPO activity in poor quality beans results from exhaustion of the substrate supply by the enzyme and also reflects inactivation of the enzyme by quinones formed during the oxidation of phenols. With the exception of the non-irrigated plants, the other treatments in Adamantina had lower phenol content than at the other two localities.

The mean weight of 100 beans and the mean seed size for coffees from Mococa, Campinas and Adamantina are shown in table 2. Coffees from Adamantina were lighter but not much smaller than those from Mococa and Campinas, which suggest that they had a lower specific mass than those from the other sites. None of the compounds analyzed in the seeds were present in significantly greater amounts in the coffee beans from Adamantina (table 1). This lack of difference may be related to the cell size and/or to the presence of a thinner cell wall.

Table 2. Weight of 100 seeds. mean seed size, cup quality and global quality of the beverage prepared from coffee cultivated without irrigation (NI), continuous irrigation (CI) irrigation suspended for 30 days (I30) and 60 days (I60) in Adamantina (AD). Mococa (MC) and Campinas (CP).

\begin{tabular}{|c|c|c|c|c|c|c|}
\hline \multirow{2}{*}{ Treatments } & \multirow{2}{*}{$\begin{array}{l}\text { Weight of } 100 \\
\text { seeds }(\mathrm{g})\end{array}$} & \multirow{2}{*}{$\begin{array}{c}\text { Mean } \\
\text { seed } \\
\text { size }\end{array}$} & \multicolumn{3}{|c|}{ Cup quality* } & \multirow{2}{*}{$\begin{array}{l}\text { Global } \\
\text { quality }\end{array}$} \\
\hline & & & $\mathrm{C} 1$ & $\mathrm{C} 2$ & $\mathrm{C} 3$ & \\
\hline NI-AD & 11.0 & 16.0 & Hard & Hard-Green & Hard & 2 \\
\hline IC-AD & 12.0 & 16.5 & Hard-plus & Hard-Green & Just soft & 2 \\
\hline $\mathrm{I} 30-\mathrm{AD}$ & 12.6 & 16.9 & Hard & Hard-Green & Hard & 1 \\
\hline I60-AD & 12.0 & 17.2 & Just soft & Hard-Green & Just soft & 2 \\
\hline NI-MC & 14.7 & 18.0 & Just soft & Hard & Just soft & 2 \\
\hline IC-MC & 14.5 & 16.8 & Hard-Fermented & Hard & Hard & 3 \\
\hline I30-MC & 14.6 & 16.9 & Hard & Hard & Hard & 2 \\
\hline I60-MC & 14.6 & 17.0 & Hard & Hard & Hard & 3 \\
\hline NI-CP & 14.6 & 16.9 & Hard & Hard-Green & Hard & 3 \\
\hline IC-CP & 14.7 & 17.1 & Hard-Green & Hard-Green & Hard & 2 \\
\hline $\mathrm{I} 30-\mathrm{CP}$ & 13.4 & 16.7 & Hard & Hard-Green & Hard & 2 \\
\hline $\mathrm{I} 60-\mathrm{CP}$ & 14.3 & 17.0 & Hard-plus & Hard & Hard & 2 \\
\hline
\end{tabular}

* C1. C2 and C3 = cup tasters 
Three tasters from the regions of Adamantina (C1), Mococa (C2) and São Paulo (C3) (table 2) analyzed the coffees for cup quality. The first two tasters were from coffee cooperatives and the third was from a trading office specializing in the classification and exportation of coffee. The sensorial analysis was unable to differentiate the coffees. However, global quality, which includes other attributes, tended to classify the coffee from Mococa as better than that from two other localities but did not have a strong influence in distinguishing the coffees when included in the PCA analysis (figure 2). Some statistical studies have argued against the ability of tasters to classify coffee cup quality (Carvalho et al., 1994). Indeed, tasters trained with a narrow variety of coffee quality may not develop the ability to evaluate coffee from other places. In addition, tasters may lose their capacity to distinguish coffees if they frequently evaluate coffees from the same place. This could have been the case of tasters $\mathrm{C} 1$ and $\mathrm{C} 2$.
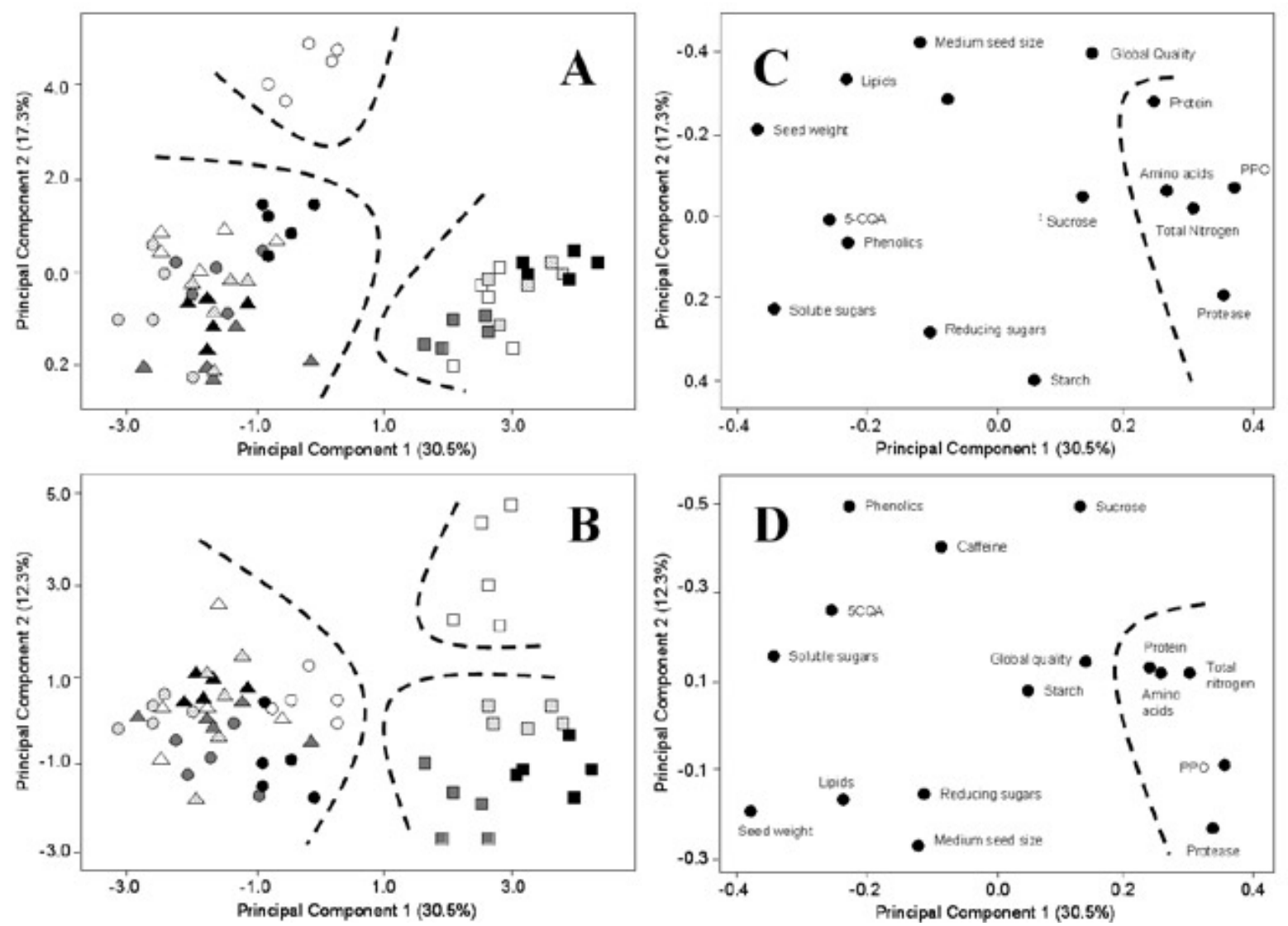

Figure 2. Principal component analyses using data for chemical composition, seed weight, mean seed size and global quality of coffee seeds. The score diagrams (A and B) show five replicates for the treatments without irrigation (NI - open symbols), continuous irrigation (CI - dotted symbols), and irrigation suspended for 30 days (I30 - grey symbols), and 60 days (I60 - black symbols) in Adamantina ( $\square$ ), Campinas (r) and Mococa $(\triangle)$. The loading diagrams (C and D) show the data for chemical composition, seed weight, mean seed size and global quality of coffee seeds $(\mathrm{O})$. The traces show groups formed. 
differences among the localities were a consequence of the air temperature in each region of cultivation. Although soil composition and attacks by insect pests could have been important factors, appropriate fertilization and pest control were practiced in the three areas during the study.

Coffee does not tolerate a wide range of temperatures. Mean temperatures below $16^{\circ} \mathrm{C}$ and above $23^{\circ} \mathrm{C}$ are not suitable and the optimum temperature for coffee growth ranges from $18^{\circ} \mathrm{C}$ to $21^{\circ} \mathrm{C}$ (Alègre, 1959; Camargo et al., 1992). During the present work $(2001 / 02)$, the mean annual temperature in Adamantina was $24.5^{\circ} \mathrm{C}$, about $2.5^{\circ} \mathrm{C}$ warmer than the upper limit of $22^{\circ} \mathrm{C}$ for coffee. In Mococa and Campinas the temperatures were $22.9^{\circ} \mathrm{C}$ and $22.3^{\circ} \mathrm{C}$, respectively.

In their assessment of the appropriate climate for producing a good quality beverage in the most important coffee-growing regions of Brazil, Camargo et al. (1992) defined the region of Adamantina as marginal, because of its high temperature. More recently, in Honduras, differences in the quality of coffees cultivated in different areas were reported by Decazzi et al. (2003). Using PCA, these authors also found that coffee quality was associated with altitude, with the best coffees occurring at altitudes above $1,000 \mathrm{~m}$, where the annual rainfall was relatively low (around 1,500 mm). However, no association with temperature was established, despite of the fact that temperature and altitude are inversely related factors. The data presented here were obtained from coffee plantations at maximum altitudes of 663, 669 and $443 \mathrm{~m}$ in Mococa, Campinas and Adamantina respectively.

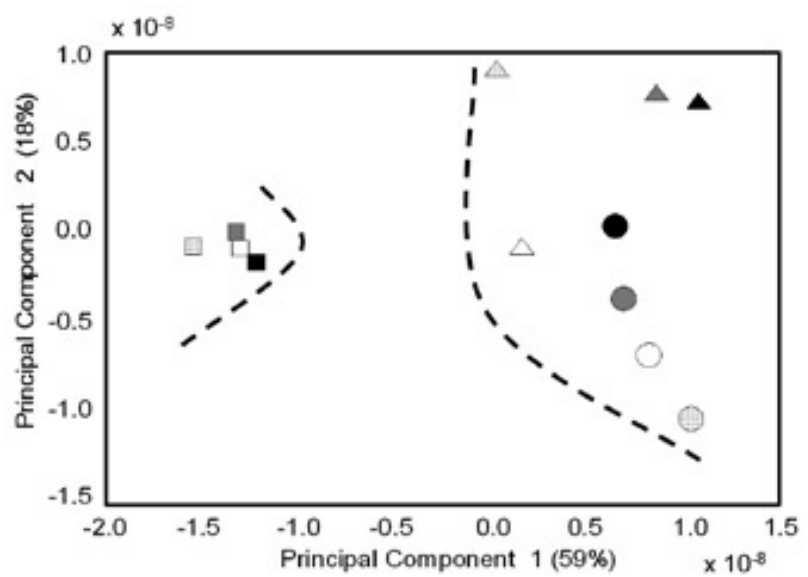

Figure 3. Principal component analysis of the data obtained with the electronic tongue used to evaluate coffee from the treatments without irrigation (NI - open symbols), continuous irrigation (CI - dotted symbols), and irrigation suspended for 30 days (I30 - grey symbols), and 60 days (I60 - black symbols) in Adamantina $(\square)$, Campinas $(\triangle)$ and Mococa $(O)$. The traces show groups formed.
The results of this study show that temperature, but not the availability of water, may be an important factor responsible for the differences in the quality and chemical composition of coffee from three regions in Brazil. The main differences were related to nitrogen-containing compounds. Enzymes such as proteases may play an important role in controlling the levels of amino acids, peptides and polypeptides that, together with carbohydrates have been implicated as key compounds in determining the quality of coffee as a beverage. Therefore, studies with controlled temperature, composition of nitrogenous compounds and coffee cup quality are presently underway to confirm the data obtained here from the field.

Acknowledgment: This work was supported by Consórcio Brasileiro de Pesquisa e Desenvolvimento do Café - Embrapa (CBP \& D/Café - Embrapa). E.A. Silva, P. Mazzafera and O. Brunini are supported by research fellowships from Conselho Nacional de Desenvolvimento Científico e Tecnológico (CNPq).

\section{REFERENCES}

Alègre, C (1959). Climats et caféiers d'Arabie. Agron. Trop. 14:23-58.

Amorim HV, Amorim VL (1977). Coffee enzymes and coffee quality. In: Ory RL, St. Angelo AJ (eds), Enzymes in Food and Beverage processings. ACS Symposium series, vol. 47. pp. 27-56. American Chemical Society, London.

Amorim HV, Melo M (1989) Significance of enzymes in nonalcoholic coffee beverage. In: Fox PF (ed), Food Enzymology, pp.189-209. Elsevier Applied Science, London.

Barrett AJ (1986). The classes of proteolytic enzymes. In: Dalling MJ (ed), Plant Proteolytic Enzymes, vol. 1, pp.1-16. CRC Press Inc., Boca Raton

Bradford MN (1976) A rapid and sensitive method for the quantification of microgram quantities of protein utilizing the principle of protein dye-binding. Anal. Biochem. 72: 248-254.

Camargo AP, Santinato R, Cortez JG (1992) Aptidão climática para qualidade da bebida nas principais regiões cafeeiras de Arábica no Brasil. In: Anais do $18^{\circ}$ Congresso Brasileiro de Pesquisas Cafeeiras, Araxá, Minas Gerais, Brasil. p.70-74.

Camargo AP, Camargo MBP (2001) Definição e esquematização das fases fenológicas do cafeeiro Arábica nas condições do Brasil. Bragantia 60: 65-68.

Carr MKV (2001) The water relations and irrigation requirements of coffee. Expl. Agric. 37:1-36.

Carvalho A (1988) Principles and practice of coffee plant breeding for productivity and quality factors: Coffea arabica. In:. Clarke RJ, Macrae R (eds), Coffee, vol. IV. pp.129-160. Elsevier Applied Science. London. 
Carvalho VD, Chagas SJR, Chalfon SM, Botrel N, Juste Jr ESG (1994) Relação entre a composição físico-química e química do grão beneficiado e qualidade de bebida do café. Pesq. Agrop. Bras. 29:449-454.

Chabrol E, Charonnat R (1937) Une nouvelle reaction pour l'étude des lipids. L'eleidemie. Press. Med. 45:17131714.

Cannell MGR (1985) Physiology of the coffee crop. In: Clifford MN, Wilson KC (eds), Coffee: Botany, Biochemistry and Production of Beans and Beverage, pp.108-134. AVI Publishing Company, Inc. Westport, CN.

Clarke RJ (1985) Green coffee processing. In: Clifford MN, Wilson KC (eds), Coffee: Botany, Biochemistry and Production of Beans and Beverage, pp.230-250. AVI Publishing Company, Inc. Westport, CN.

Clifford MN (1985) Chemical and physical aspects of green coffee and coffee products. In: Clifford MN, Wilson KC (eds), Coffee: Botany, Biochemistry and Production of Beans and Beverage. pp.305-374. AVI Publishing Company, Inc. Westport, CN.

Clifford MN (1997) The nature of chlorogenic acids: Are they advantageous compounds in coffee? In: Proceedings of the $17^{\text {th }}$ International Scientific Colloquium on Coffee, Kenya. ASIC, Paris, pp. 79-91.

Cocking EC, Yemm EW (1954) Estimation of amino acids by ninhydrin. Biochem. J. 58, xii-xiii.

Decazy F, Avelino J, Guyot B, Perriot JI, Pineda C, Cilas C (2003) Quality of different Honduran coffees in relation to several environments. J. Food Sci. 68:2356-2361.

Fazuoli LC, Gallo PB, Cervellini GJ, Barros I, Van Raij B, (1998) Café. In: Fal JI, Camargo MBP, Pizzinato MA, Betti JA, Melo AM, De Maria IC, Furlani AMC (eds), Instruções Agrícolas para as Principais Culturas - Boletim 200, Instituto Agronômico de Campinas, Campinas, São Paulo, Brasil.

Ferreira M, Riul Jr. A, Wohnrath K, Fonseca FJ, Oliveira Jr. ON, Mattoso LHC (2003) High performance taste sensor made from Langmuir-Blodgett films of conducting Polymers and Ruthenium complex. Anal. Chem. 75:953-955.

Folstar P (1985) Lipids. In: Clarke RJ, Macrae R (eds), Coffee: Chemistry, vol. II, pp.203-222. Elsevier Applied Science, London.

Guyot B, Gueule D, Manez JC, Perriot JJ, Giron J, Vilain J, (1996) Influence de l'altitude et de l'ombrage des cafés Arabica. Plantat Rech. Dév. 3:272-280.

Krug CA (1940) O cálculo da peneira média na seleção do cafeeiro. Rev. Inst. Café 15:123-127.

Ludwig E, Lipke U, Raczek U, Jager A (2000) Investigations of peptides and proteases in green coffee beans. Eur. Food Res. Technol. 211:111-116.

Mazzafera P (1997) Maté drinking caffeine and phenolic acid intake. Food Chem. 60:67-71.

Mazzafera P (1999) Chemical composition of defective coffee beans. Food Chem. 64:547-554.
Mazzafera P, Robinson SP (2000) Characterization of polyphenol oxidase in coffee. Phytochemystry 55:285-296.

Mazzafera P, Gonçalves KV, Shimizu MM (2002) Extração e dosagem da atividade da polifenoloxidase do café. Scien. Agric. 59:695-700.

McReady RM, Guggloz J, Silveira V, Owens HS (1959) Determination of starch and amylose in vegetables: applications to peas. Anal. Chem. 22:1156-1158.

Moreira RFA, Trugo LC, De Maria CAB, Matos AGB, Santos SM, Leite JMC (2001) Discrimination of Brazilian arabica green coffee samples by chlorogenic acid composition. Arch. Latin. Nutr. 51(1):94-99.

Montavon P, Duruz E, Rumo G, Pratz G, (2003a) Evolution of green coffee protein profile with maturation and relationship to coffee cup quality. J. Agric. Food Chem. 51: 2328-2334.

Montavon P, Mauron A-F, Duruz E (2003b) Changes in green coffee protein profiles during roasting. J. Agric.Food Chem. 51:2335-2343.

Morgano MA, Queiroz SCN, Ferreira MMC (1999) Application of exploratory analysis to the differentiation of vegetables. Braz. J. Food Technol. 2:73-79.

Nelson N (1944) A photometric adaptation of the Somogy method for the determination of glucose. J. Biol. Chem. 153:375-380.

Njoroge JM (1998) Agronomic and processing factors affecting coffee quality. Out. Agric. 27:163-166.

Oliveira AS, Pereira RA, Lima LM, Morais AHA, Melo FR, Franco OL, Bloch Jr. C, Grossi-de-Sá MF, Sales MP (2002) Activity toward bruchid pest of a kunitz-type inhibitor from seeds of the algaroba tree (Prospis juliflora D.C.). Pestic. Biochem. Physiol. 72:122-132.

Pearson D (1976) The chemical analysis of foods. $7^{\text {th }}$ edn. Chuchill Livingstone, London.

Pirouette (1997) Multivariate Data Analysis for IBM PC Systems, version 2.2. Infometrix, Seatle, WA, USA.

Prado H (2003) Solos do Brasil: gênese, morfologia, classificação, levantamento e manejo. $3^{\text {th }}$ edn., Piracicaba, SP, Brasil. ISBN 85-901330-1-X

Riul Jr A, Solo AMG, Mello SV, Bone S, Taylor DM, Mattoso LHC (2003) An electronic tongue using polypyrrole and polyaniline. Synth. Metals 132:109-116.

Rogers WJ, Bézard G, Deshayes A, Meyer I, Petiard V, Marraccini $\mathrm{P}$ (1999a) Biochemical and molecular characterization and expression of the 11S-type storage protein from Coffea arabica endosperm. Plant Physiol. Biochem 37:261-272.

Rogers WJ, Michaux J, Bastin M, Bucheli P (1999b). Changes to the content of sugar, sugar alcohols, myo-inositol, carboxylic acid and inorganic anions in developing grains from different varieties of Robusta (Coffea canephora) and Arabica (C. arabica) coffees. Plant Sci. 149:115-123.

Russo Jr M (1984) Dados climáticos auxiliares para planejamento e projeto de sistemas de irrigação. São Paulo, Companhia Energética de São Paulo. 13p. 
Silva EA (2004) Influência de distintas condições edafoclimáticas e do manejo de irrigação no florescimento, produção e qualidade de bebida do café (Coffea arabica L.). Campinas, Universidade Estadual de Campinas. PhD thesis.

Scholz MBJ, Prete CEC, Crudj E, Magri TB (2001) Composição química de variedades de café (Coffea arabica). In: I Simpósio de Pesquisa dos Cafés do Brasil. Poços de Caldas, MG, Brasil. pp. 673-676.

Selmar D, Bytof G, Knopp S-E (2001) New aspects of coffee processing. The relation between seed germination and coffee quality. In: Proceedings of the $19^{\text {th }}$ International Scientific Colloquium on coffee, Helsinki. ASIC, Paris. CD-Rom.

Shimizu MM, Mazzafera P (2000) Compositional changes of proteins and amino acids in germinating coffee seeds. Braz. Arch. Biol. Technol. 43:259-265.
Soil Survey Staff (1999) Soil taxonomy: a basic system of soil classification for making and interpreting soil surveys, $2^{\text {nd }}$ edn. USDA, Natural Resources Conservation Service, Agricultural Handbook 436; US Government Printing Office: Washington DC.

Swain T, Hillis WE (1959) The phenolic constituents of Prunus domestica. I: The quantitative analysis of phenolic constituents. J. Sci. Food Agric. 10:63-68.

Trugo LC, Macrae RA (1984) Study of the effect of roasting on the chlorogenic acid composition of coffee using HPLC. Food Chem. 15:219-227.

van Handel E (1968) Direct microdetermination of sucrose. Anal. Biochem. 22:280-283.

Vincent JC (1985) Green coffee processing. In: Clarke RJ, Macrae R (eds), Coffee: Chemistry, vol. II., p.1-33. Elsevier Applied Science, London. 